\title{
Sustainable earth walls to meet the building regulations
}

\section{Steven Goodhew and Richard Griffiths}

${ }^{\text {a }}$ School of Civil Engineering, University of Plymouth, Reynolds Building, Drake Circus, Plymouth PL4 8AA, UK

${ }^{\mathrm{b}}$ School of Architecture and Design, University of Plymouth, Hoe Centre, Notte Street, Plymouth PL1 2AR, Devon, UK

Received 25 May 2004; revised 24 July 2004; accepted 10 August 2004. Available online 1 October 2004.

\begin{abstract}
The thermal conductivity and diffusivity of un-fired clay bricks, a straw clay mixture and straw bales have been measured using a thermal probe technique, with an iterative method for data analysis. The steady-state air-to-air thermal transmittance, or $U$ value, and the time-dependent thermal properties of some proposed sustainable earth wall constructions are presented. Sustainable cavity walls of un-fired clay bricks with paper, straw or wool cavity insulation have thermal transmittances less than $0.35 \mathrm{~W} / \mathrm{m}^{2} \mathrm{~K}$, and therefore meet the current United Kingdom Building Regulations. A review of possible methods for thermally up-grading existing earth walls, by adding an internal insulated timber frame construction, again demonstrates possible compliance with the current UK thermal regulations.
\end{abstract}

Keywords: Sustainable walls; Earth construction; Thermal transmittance; Building regulations

\section{Article Outline}

1. Introduction

2. Aims

3. Probe technique

4. Materials

4.1. Bricks

4.2. Straw bale

4.3. Straw-clay mixture

4.4. Pads

5. Calculation of the time-dependent properties of walls

6. Results and discussion

6.1. Thermal properties of materials studied in this work

6.2. Thermal properties of materials required for the proposed wall constructions

6.3. Thermal properties of proposed sustainable earth walls 
6.4. Thermal properties of upgraded earth walls with external glazing

6.5. Thermal properties of upgraded earth walls with internal insulated timber frame

7. Conclusions

References

\section{Introduction}

Sustainable earth walls can be designed to meet modern building standards. Vernacular earth walls built in the South West of England are known as cob walls. These walls are constructed using a mixture of earth and straw placed in layers on a stone plinth. Earth walls constructed in the past were engineered to be structurally sufficient. The builders of these walls knew nothing of the current Building Regulations, "Conservation of Fuel and Power. Approved document L1 Conservation of fuel and power in dwellings" [1], nor worried about fuel efficiency or embodied energy. Today there is a need to minimise the use of energy and the production of carbon dioxide. To this end sustainable building materials are sought, materials that will provide a thermally efficient wall, while at the same time walls that will not require large amounts of energy in the construction or deconstruction processes. The assessment of the energy involved in the life-cycling of materials is a complex problem [2], which will not be considered here. Given that earth walls represent a possible and sustainable solution, two factors must be considered so that these walls are acceptable. Firstly, the thermal data of earth walls must be known and secondly, these earth walls must have a thermal performance that can be demonstrated to meet the modern building standards. There are two aspects of earth walling that need to be addressed: (a) new buildings of earth and (b) the upgrading and repair of existing walls. In the design proposal for a new building, the steady-state air-to-air thermal transmittance, or $U$-value, of the walls must be considered, and compared with the building standards to seek compliance. Currently, the United Kingdom regulations require that the wall should have a $U$-value of $0.35 \mathrm{~W} / \mathrm{m}^{2} \mathrm{~K}$. The historic earth walls in Devon with thickness in the region of $600 \mathrm{~mm}$ have $U$-values far larger than the modern requirement. The cob cottage in Devon had the reputation of being cosy in winter and cool in the summer. The explanation for this may lie in the time-dependent behaviour of the walls not just in the steady-state case where the $U$-values are relevant. The large thermal mass [3] allows the external temperature cycling to be smoothed so that relatively small internal temperature fluctuations are observed. The second application of earth is in the repair and conservation of our heritage buildings. English Heritage [4] reminds us that the changes in the UK Building Regulations [1], part "L", arise partly due to the need to reduce the carbon dioxide emissions (Kyoto Protocol). English Heritage must be able to demonstrate that their buildings are sustainable. Often this is difficult since the thermal properties of the buildings are unknown, and repairs are made with traditional materials often of unknown thermal properties. Moreover, the National Physical Laboratory identifies further goals in their work, "Standards for heat transfer through structures" [5]. Firstly, there is the need to develop materials and products with improved thermal performance and secondly, there is the need to develop the dynamic thermal modelling of buildings. The current UK Building Regulations employ steady-state thermal models, $U$-values for heat transfer, while clearly a real building is rarely in a steady-state. Improved modelling 
of the thermal performance of buildings with real thermal properties of the constituent materials is therefore an important goal.

United Kingdom built environment professionals use the CIBSE Environmental Design Guide A 1999 [6] for guidance on the thermal properties of different constructions. However, in the section on walls, CIBSE 1999 [6], pages 3-59 to 3-60, there are only three entries describing constructions with $U$-values less that $0.35 \mathrm{~W} / \mathrm{m}^{2} \mathrm{~K}$.

\section{Aims}

This paper will present thermal data on some sustainable earth based materials, suitable for walls. The thermal properties of these materials have been obtained using a novel thermal probe technique involving an iterative method of data analysis for determining simultaneously the thermal conductivity and diffusivity [7]. It is important to stress that the time-dependent thermal properties of built constructions are a function of the material volumetric heat capacity, which is the ratio of thermal conductivity to diffusivity. For the steady-state properties, only the thermal conductivity is required. Here, in this paper, calculations and discussion will compare both the steady-state and time-dependent thermal properties of some proposed earth wall constructions with wall construction given in the CIBSE Guide [6]. Moreover, the possibility of modifying existing earth walls to meet the current regulations will be discussed.

Three aims can be identified:

(1) To report the thermal properties of three sustainable building materials measured using the thermal probe technique with iterative data analysis.

(2) To determine the thermal properties of some proposed sustainable walls and to compare their thermal performance with that of less sustainable wall constructions.

(3) To demonstrate how the thermal properties of existing earth walls might be upgraded to meet the current United Kingdom Building Regulations.

\section{Probe technique}

The Hukseflux [8] thermal probe, type TP02, was used for these studies. This probe is $150 \mathrm{~mm}$ long and $1.5 \mathrm{~mm}$ in diameter. The external sheath of the probe is stainless steel and contains two internal thermojunctions, and the $100 \mathrm{~mm}$ long hairpin heater. At the base is a platinum-resistance thermometer to determine the ambient temperature. The two internal thermojunctions are used to measure the rise in probe temperature as a function of time, when a constant heater current is maintained. A recipe has been developed to identify the appropriate time window when the rise in probe temperature as a function of the natural logarithm of the elapsed heating time should be analysed. Microsoft Excel Solver routines are used to find iterative solutions for the sample thermal conductivity and volumetric heat capacity. Full details are given by Goodhew and Griffiths [7]. 


\section{Materials}

The thermal probe technique has been used to measure the thermal properties of three sustainable materials. Both the thermal conductivity and the diffusivity have been measured, and the volumetric heat capacity calculated.

The three materials studied were: (1) unfired clay bricks, (2) straw bales and (3) straw-clay. The bricks and straw-clay are examples of structural building materials, while the straw bale was to be an in-fill insulator.

\subsection{Bricks}

The bricks were Claytec unfired clay bricks, type 7002DF, Construction Resources [9], with a composition of clay-silt-sand mixed with straw and wood chippings. The ratio of the clay-silt-sand mixture to straw was between 1:2 and 1:3, according to Dewar [10]. The manufacturer does not give any more information about the composition of these bricks. The bricks are nominally $240 \mathrm{~mm}$ by $115 \mathrm{~mm}$ by $113 \mathrm{~mm}$ and the density is given as $700 \mathrm{~kg} / \mathrm{m}^{3}$. The supplier provides a light clay mortar for constructing clay brick walls. Holes $150 \mathrm{~mm}$ long and $1.5 \mathrm{~mm}$ diameter were carefully drilled in the bricks. Toothpaste was used to ensure good thermal contact between the thermal probe and the brick material.

\subsection{Straw bale}

The straw bale samples were measured as produced by an agricultural bailer. The bales were $360 \mathrm{~mm}$ by $615 \mathrm{~mm}$ by $610 \mathrm{~mm}$ with a density of $60 \mathrm{~kg} / \mathrm{m}^{3}$, and were supplied by a local farmer.

\subsection{Straw-clay mixture}

This material was a relatively dense mixture of straw with clay made in the shape of a cylinder $300 \mathrm{~mm}$ in diameter and $350 \mathrm{~mm}$ high. The material had a density of $440 \mathrm{~kg} / \mathrm{m}^{3}$. This material was supplied by Lysana Robinson from a sample of a material being used for a light clay wall.

\subsection{Pads}

Data on the thermal conductivity and diffusivity of the pads were reported earlier [7] and this material will also be used as an insulator. The pads were made from straw with a little clay, and were produced as part of the Department of Trade and Industry "Partners in Innovation" programme to investigate the potential of "Light Earth Construction" for the UK [11]. The straw-clay pads were approximately $150 \mathrm{~mm}$ cubes and consisted of cut lengths of straw in layers to the depth of $150 \mathrm{~mm}$. The straw was then fixed by allowing a semifluid clay water mixture, a slip, to drain through the pads. When dry the clay held the straw together to produce a reasonably firm cube.

Having described the materials for this study, the next section will outline the method for calculating the thermal properties of some constructions. 


\section{Calculation of the time-dependent properties of walls}

The steady-state thermal transmittance and the time-dependent thermal properties of the various walls were calculated using Hevacomp Ltd. software [12], program MAT version 16.00. All the MAT calculations presented here were performed with normal weather exposure, although other exposure settings can be selected from within the software.

The internal and external surface resistances were taken as 0.120 and $0.060 \mathrm{~m}^{2} \mathrm{~K} / \mathrm{W}$ respectively. The solid layers were defined in terms of thickness and their thermal conductivity, density and specific heat capacity. Air cavity data was stored within the Mat software and was simply selected.

Following the timber frame technique, it is proposed that an external leaf of claytec bricks or earth walling like cob be used in place of the more common brick, block or stone work. Problems of moisture penetration, structural stability and buildability would need to be considered carefully. Here only the thermal properties will be discussed.

\section{Results and discussion}

Following the aims stated earlier, the results of the experimental work will be presented first. This will be followed by the presentation of the thermal properties of the existing cob walls, the thermal design of new build walls and, finally, the thermal upgrading of existing cob walls will be considered.

\subsection{Thermal properties of materials studied in this work}

Table 1 shows the measured values of the thermal conductivity and thermal diffusivity of the three building materials studied in this work. The probe technique with an iterative method of data analysis gives these two parameters, and with knowledge of the density of the materials the specific heat capacity is calculated. As expected the behaviour of the straw bale was similar to that of thatch, see Table 2 for comparison. There is some confusion in the literature concerning the value of the specific heat capacity of thatch. The CIBSE guide [6] gives the specific heat as $180 \mathrm{~J} / \mathrm{kg} \mathrm{K}$, while Szokolay [13], page 248, quotes the specific heat capacity of thatch as $1420 \mathrm{~J} / \mathrm{kg} \mathrm{K}$. The straw-clay mixture can be used in any thickness, and traditional cob walls can be designed using this material. The Claytec bricks can be used in a variety of ways, for example as an adobe wall construction [14]. 


\begin{tabular}{|c|c|c|c|c|c|}
\hline & $\begin{array}{l}\text { Density, } \\
\rho \\
\left(\mathbf{k g} / \mathbf{m}^{3}\right)\end{array}$ & $\begin{array}{l}\text { Thermal } \\
\text { conductivity, } \\
\lambda\left(\mathbf{W} \mathbf{m}^{-1} \mathbf{K}^{-1}\right)\end{array}$ & $\begin{array}{l}\text { Diffusivity, } \alpha \\
\left(\times 10^{7} \mathrm{~m}^{2} \mathrm{~s}^{-1}\right)\end{array}$ & $\begin{array}{l}\text { Volumetric heat } \\
\text { capacity, } \lambda / \alpha \\
\left(\times 10^{-3} \mathbf{J ~ m}^{-3} \mathbf{K}^{-1}\right)\end{array}$ & $\begin{array}{l}\text { Specific } \\
\text { heat } \\
\text { capacity, } \\
\lambda / \alpha \rho \\
(\mathrm{J} / \mathbf{k g ~ K})\end{array}$ \\
\hline Straw bale & 60 & $0.067(0.002)$ & $18.2(0.5)$ & $36.8(0.7)$ & $600(10)$ \\
\hline Clay-straw mixture & 440 & $0.18(0.01)$ & $4.6(0.4)$ & $400(50)$ & 900 (100) \\
\hline Bricks, claytec & 800 & $0.24(0.02)$ & $3.8(0.3)$ & $650(20)$ & $750(30)$ \\
\hline
\end{tabular}

The values inside the parentheses are standard deviation.

Table 2.

The thermal properties of the additional materials used in the calculations and comparisons

\begin{tabular}{|c|c|c|c|c|c|c|}
\hline & $\begin{array}{l}\text { Density, } \\
\rho \\
\left(\mathrm{kg} / \mathrm{m}^{3}\right)\end{array}$ & $\begin{array}{l}\text { Thermal } \\
\text { conductivity, } \\
\lambda \\
\left(\mathbf{W} \mathbf{m}^{-1} \mathbf{K}^{-1}\right)\end{array}$ & $\begin{array}{l}\text { Specific } \\
\text { heat } \\
\text { capacity, } \\
\text { c } \\
\left(\mathbf{J} / \mathbf{k g ~ K}^{\mathbf{1}}\right)\end{array}$ & $\begin{array}{l}\text { Volumetric heat } \\
\text { capacity, } \rho c \\
\left(\times 10^{-3} \mathrm{~J} \mathrm{~m}^{-3} \mathrm{~K}^{-1}\right)\end{array}$ & $\begin{array}{l}\text { Diffusivity, } \\
\lambda / \rho c \\
\left(\times 10^{7} \mathrm{~m}^{2} \mathrm{~s}^{-1}\right)\end{array}$ & Reference \\
\hline Paper (cellulosic insulation) & 43 & 0.042 & 1380 & 59.34 & 7.08 & {$[6$, p. 3-45] } \\
\hline Pads (straw + clay slip) & 110 & 0.073 & 425 & 46.8 & 15.6 & {$[7$, p. 220] } \\
\hline Wool & 140 & 0.038 & 840 & 117.6 & 3.23 & {$[6$, p. 3-45] } \\
\hline Plywood sheathing & 700 & 0.15 & 1420 & 994 & 1.51 & {$[6$, p. 3-51] } \\
\hline Plasterboard & 950 & 0.16 & 840 & 798 & 2.01 & {$[6$, p. 3-47] } \\
\hline Cob (Devon earth, mean) & 1450 & 0.45 & 800 & 1153 & 3.93 & {$[17$, p. 142} \\
\hline Clay (USA) & 1460 & 1.3 & 880 & 1285 & 10.12 & {$[18$, p. 755} \\
\hline Glass (soda-lime) & 2500 & 1.05 & 840 & 2100 & 5.00 & {$[6$, p. 3-44] } \\
\hline \multicolumn{7}{|l|}{ For comparison } \\
\hline Glass fibre quilt & 12 & 0.04 & 840 & 10.1 & 39.7 & {$[6$, p. 3-45] } \\
\hline Blown glass fibre & 16 & 0.043 & 835 & 13.4 & 32.2 & {$[18$, p. 752} \\
\hline Thatch & 240 & 0.07 & 180 & 43.2 & 16.2 & {$[6$, p. 3-59] } \\
\hline
\end{tabular}

\subsection{Thermal properties of materials required for the proposed wall constructions}


Table 2 shows the thermal properties of the other materials used in the design of the sustainable walls. It is proposed to use only sustainable insulation materials, like Warmcel [15], manufactured from recycled newsprint treated to enable its use as a cavity filling for wall constructions; or wool as Thermafleece [16]. Both these materials have low embodied energies, although transport energy would need to be considered in a full life-cycle analysis. The pads, formed from a layer of straw loosely held together with a little clay, are again to be used as a building insulator. The plywood sheathing and plasterborad are used in a timber frame construction, similar to that used in brick or stone exterior timber framed buildings here in the UK. In order to explore a range of possible earth walls the measured thermal data on some Devon cob walls is included, along with data on clay from the USA. The data published in the Terra 2000 conference [17] has been used to give a mean value for Devon cob walls. In Table 2 the difference between the thermal conductivity for clay (USA) and cob (Devon earth) lies in the different compositions and possible moisture content of the real walls represented by the cob value. Data on soda-lime window glass is given for the modelling of possible cladding of earth buildings. Finally, for comparison with the novel materials presented here, the data for glass fibre quilt, blown glass fibre and thatch are included in Table 2.

\subsection{Thermal properties of proposed sustainable earth walls}

We will consider some new build options and the possible upgrading of traditional cob walls to modern thermal standards. New build is relatively straightforward, the wall can be designed and the $U$-value calculated along with the time-dependent thermal properties like the admittance and decrement factor. The modification of existing walls is more complex. The simplest modification is to build some thermal structure inside the building. However, this will cause inconvenience to the owners while the work is undertaken and will reduce the habitable volume of the building. The external appearance will not be altered, which is an important aspect of maintaining and modernising our heritage buildings.

$\underline{\text { Table } 3}$ presents the thermal performance data for some proposed earth walls. The data is given in a similar style to the CIBSE tables in chapter 3 of the Environmental Design Guide A [6]. The thickness of the proposed wall is given again for comparative purposes. The steady-state air-to-air thermal transmittance, or $U$-value, is given with the mass per unit area of the wall. Then the time-dependent thermal properties are given. For thermal modelling, using the Admittance method, see CIBSE Guide Section A5, 1986, five time-dependent quantities are required. These are (1) the surface factor, (2) the time lag of the surface factor, (3) the admittance, (4) the decrement factor and (5) the decrement factor time lag. Table 3 gives these values for a number of proposed wall constructions. At the top of the table are three wall constructions, walls 3.1-3.3, reproduced from the CIBSE Guide [6]. They have been selected since they satisfy the current Building Regulations with a $U$-value of $0.35 \mathrm{~W} / \mathrm{m}^{2} \mathrm{~K}$ or less. The first example, wall 3.1, is a standard brick-block wall with blown fibre insulation, while the second two, walls 3.2 and 3.3, are timber-framed walls, one with $95 \mathrm{~mm}$ insulation between studs and the second with $140 \mathrm{~mm}$ of insulation. The steady-state thermal performance of walls 3.1 and 3.2, walls with $100 \mathrm{~mm}$ of insulation, are the same; while the addition of $40 \mathrm{~mm}$ of blown fibre gives a $U$-value improvement of about $30 \%$ in wall 3.3. Table 3 goes on to show the proposed walls, firstly there are two solid walls, wall 3.4 is of $600 \mathrm{~mm}$ of straw-clay 
mixture, which might be identified as a new build version of a traditional Devon cob wall. The next wall, wall 3.5, has $810 \mathrm{~mm}$ of bricks by Claytec, representing an adobe wall, a wall that is constructed of unbaked earth bricks held together with a loam mortar. The thickness is obtained by having three $110 \mathrm{~mm}$ bricks lying parallel to the wall face and two at right angles. The thickness is 3 times 110 plus 2 times $240 \mathrm{~mm}$ or $810 \mathrm{~mm}$. This solid brick wall has to be more than $800 \mathrm{~mm}$ thick for the $U$-value to fall to an acceptable $0.29 \mathrm{~W} / \mathrm{m}^{2} \mathrm{~K}$. The decrement factor time lag is more than $24 \mathrm{~h}$, and would provide considerable thermal damping. The interior of a building with walls constructed in this way might be expected to be cool in summer and warm in winter.

\begin{tabular}{|l|l|l|l|l|l|l|l|}
\hline $\begin{array}{l}\text { Thickness } \\
(\mathbf{m m})\end{array}$ & $\begin{array}{l}\boldsymbol{U} \text {-value } \\
\left(\mathbf{W} / \mathbf{m}^{2} \mathbf{K}\right)\end{array}$ & $\begin{array}{l}\text { Mass } \\
\text { per } \\
\text { unit } \\
\text { area } \\
\left(\mathbf{k g} / \mathbf{m}^{2}\right)\end{array}$ & $\begin{array}{l}\text { Admittance } \\
\left(\mathbf{W} / \mathbf{m}^{2} \mathbf{K}\right)\end{array}$ & $\begin{array}{l}\text { Admittance } \\
\text { time lead } \\
(\mathbf{h})\end{array}$ & $\begin{array}{l}\text { Surface } \\
\text { factor }\end{array}$ & $\begin{array}{l}\text { Surface } \\
\text { factor } \\
\text { time } \\
\text { lag (h) }\end{array}$ & $\begin{array}{l}\text { D } \\
\text { fa }\end{array}$ \\
\hline & & & & & & & \\
\hline 318 & 0.3 & NA & 3.06 & 2.8 & 0.77 & 1.2 & 0.4 \\
\hline
\end{tabular}

(3.2) $105 \mathrm{~mm}, 50 \mathrm{~mm}$ airspace, $19 \mathrm{~mm}$ plywood sheathing,

$95 \mathrm{~mm}$ studding, $95 \mathrm{~mm}$ mineral fibre insulation between studs, $13 \mathrm{~mm}$ plasterboard

(3.3) $105 \mathrm{~mm}$ brick, $50 \mathrm{~mm}$ airspace, $19 \mathrm{~mm}$ plywood sheathing,

$140 \mathrm{~mm}$ studding $140 \mathrm{~mm}$ mineral fibre insulation between studs, $13 \mathrm{~mm}$ plasterboard

\begin{tabular}{|l|l|l|l|l|l|l|l|}
\hline & & & & & & & \\
\hline 282 & 0.29 & NA & 0.86 & 4.1 & 1 & 0.4 & 0.6 \\
\hline 327 & 0.21 & NA & 0.86 & 4.5 & 0.97 & 0.4 & 0.5 \\
\hline
\end{tabular}

(3.4) 600 mm straw-clay mixture

(3.5) $810 \mathrm{~mm}$ bricks (Claytec, clay plus straw, wood)

(3.6) $110 \mathrm{~mm}$ bricks (clay plus straw, wood), $150 \mathrm{~mm}$ straw insulation, 110 mm bricks (clay plus straw, wood)

(3.7) $110 \mathrm{~mm}$ bricks (clay plus straw, wood), $150 \mathrm{~mm}$ pads (straw + clay) insulation, $110 \mathrm{~mm}$ bricks (clay plus straw, wood)

(3.8) $110 \mathrm{~mm}$ bricks (clay plus straw, wood), $150 \mathrm{~mm}$ thermal fleece insulation, $110 \mathrm{~mm}$ bricks (clay plus straw, wood)

(3.9) 110 mm bricks (clay plus straw, wood), 150 mm Warmcel paper insulation, $110 \mathrm{~mm}$ bricks (clay plus straw, wood)

(3.10) 240 mm bricks (clay plus straw, wood), 100 mm pads (straw + clay) insulation $110 \mathrm{~mm}$ bricks (clay plus straw, wood)

(3.11) 240 mm bricks (clay plus straw, wood), $100 \mathrm{~mm}$ thermal fleece insulation, $110 \mathrm{~mm}$ bricks (clay plus straw, wood)

(3.12) $240 \mathrm{~mm}$ bricks (clay plus straw, wood), $100 \mathrm{~mm}$ Warmcel paper insulation, $110 \mathrm{~mm}$ bricks (clay plus straw, wood)

(3.13) 240 mm bricks (clay plus straw, wood), 150 mm pads (straw + clay) insulation, $110 \mathrm{~mm}$ bricks (clay plus straw, wood)

\begin{tabular}{|c|c|c|c|c|c|c|}
\hline 600 & 0.29 & 266 & 1.88 & 2.39 & 0.83 & 0.61 \\
\hline 810 & 0.29 & 648 & 2.50 & 2.18 & 0.77 & 0.82 \\
\hline 370 & 0.30 & 185 & 2.73 & 2.64 & 0.78 & 1.04 \\
\hline 370 & 0.32 & 226 & 2.70 & 2.52 & 0.77 & 0.99 \\
\hline 370 & 0.20 & 197 & 2.74 & 2.57 & 0.77 & 1.03 \\
\hline 370 & 0.22 & 183 & 2.76 & 2.62 & 0.77 & 1.05 \\
\hline 450 & 0.34 & 313 & 2.67 & 2.54 & 0.77 & 0.99 \\
\hline 450 & 0.24 & 294 & 2.73 & 2.59 & 0.77 & 1.03 \\
\hline 450 & 0.25 & 284 & 2.73 & 2.63 & 0.78 & 1.04 \\
\hline 500 & 0.27 & 330 & 2.70 & 2.52 & 0.77 & 0.99 \\
\hline
\end{tabular}


(3.14) $240 \mathrm{~mm}$ bricks (clay plus straw, wood), $150 \mathrm{~mm}$ thermal fleece insulation,

$110 \mathrm{~mm}$ bricks (clay plus straw, wood)

(3.15) 240 mm bricks (clay plus straw, wood), 150 mm Warmcel paper insulation,

$110 \mathrm{~mm}$ bricks (clay plus straw, wood)

(3.16) $240 \mathrm{~mm}$ bricks (clay plus straw, wood), $360 \mathrm{~mm}$ straw insulation, $110 \mathrm{~mm}$ brick (clay plus straw, wood)

\begin{tabular}{|l|l|l|l|l|l|l|l}
\hline 500 & 0.18 & 301 & 2.74 & 2.57 & 0.77 & 1.03 & 0.0 \\
\hline 500 & 0.19 & 287 & 2.76 & 2.62 & 0.77 & 1.05 & 0.1 \\
\hline 710 & 0.14 & 302 & 2.77 & 2.60 & 0.77 & 1.05 & 0.0 \\
\hline
\end{tabular}

Table 3.

The remainder of Table 3 shows a variety of proposed brick-insulation-brick walls. Walls 3.6-3.9 have an external leaf of $110 \mathrm{~mm}$ bricks with $150 \mathrm{~mm}$ of insulation moving from pads, to wool and to paper. These walls meet the Building Regulations with $U$-values ranging from 0.32 to $0.20 \mathrm{~W} / \mathrm{m}^{2} \mathrm{~K}$. Walls $3.10-3.12$ have external leaf of $240 \mathrm{~mm}$ brick, but now with only $100 \mathrm{~mm}$ of insulation. Here the wall with pads for insulation, wall 3.10, is marginally within the Regulations, while the wool and paper insulated walls are acceptable with $U$-values of about $0.25 \mathrm{~W} / \mathrm{m}^{2} \mathrm{~K}$. Walls 3.13-3.15 have external leaf of $240 \mathrm{~mm}$ brick with $150 \mathrm{~mm}$ of insulation. The $U$ values range from 0.27 to $0.18 \mathrm{~W} / \mathrm{m}^{2} \mathrm{~K}$, and would be acceptable. For a given external brick thickness the insulation materials may be arranged as pads, straw, paper and wool in order of decreasing $U$-value and therefore increasing thermal efficiency. The wool walls have the longer decrement time lags. In each case there is little to choose between paper and wool. Moreover, both paper and wool are commercially available. Focussing on the walls 3.10-3.15, the walls with external leaf of $240 \mathrm{~mm}$ of adobe construction bricks, walls 3.10-3.12 with $100 \mathrm{~mm}$ of insulation, walls 3.133.15 with $150 \mathrm{~mm}$ of insulation, the following may be seen in Table 3 . Increasing the thickness of the insulation decreases the $U$-value, while the admittance remains the same, the surface factor remains constant as is to be expected, the decrement factor decreases as the time lag increases. Again, as the mass of the insulation increases through paper, pads and wool the decrement factor decreases while the time lag increases.

Finally, at the bottom of Table 3 is a proposed brick wall, wall 3.16, with a straw bale $360 \mathrm{~mm}$ thick providing the insulation between $240 \mathrm{~mm}$ external brick leaf and $110 \mathrm{~mm}$ internal brick leaf. Wall 3.16 has the lowest $U$-value at $0.14 \mathrm{~W} / \mathrm{m}^{2} \mathrm{~K}$. This wall would be acceptable as an alternative to an existing cob wall in terms of thermal behaviour and thickness, and would meet the current Building Regulations.

As mentioned above there are two aspects in this work, new build and upgrading. Firstly, there is the issue of new building with proposed wall designs using sustainable materials to meet the Building Regulations. Secondly, there is the upgrading and repair of existing earth walls to meet current standards. The possibility of sustainable walls for new buildings to meet current standards has been discussed above. Before addressing the upgrading and repairing of existing cob walls, it is important to note that in one parish in Devon, Sandford for example, there are over a hundred listed earth structures, including dwellings in use [19]. For the upgrading of existing earth walls, there are two simple strategies that can be explored, one external and one internal. The first would use an external glass wall or screen to provide a ventilated air 
cavity between the external glass and the cob wall. Problems of aesthetics, structural stability and safety, moisture movement and building ventilation would need to be addressed. The second strategy would be to erect an insulated timber frame inside the cob wall. This would have a large impact on the internal spaces of some of the smaller cottages and dwellings. Again issues of aesthetics, moisture movement and vermin attack would need to be addressed. Otto [20] reminds us that sustainability has three interwoven strands. The three are: (a) the social aspects, about people, (b) the environmental aspects, about the planet and (c) the economic aspects, about the profit. Clearly, the upgrading of our heritage buildings will depend strongly on the people or social aspects of the proposed modifications. The method of upgrading the thermal performance of heritage buildings will have to be socially acceptable, as well as efficient and economic. The present work will only review the thermal properties, with the main aim being to produce a $U$-value of $0.35 \mathrm{~W} / \mathrm{m}^{2} \mathrm{~K}$ or less, and to produce the necessary input information for time-dependent thermal studies of some modelled cob buildings.

\subsection{Thermal properties of upgraded earth walls with external glazing}

To illustrate the problem of upgrading earth walls Table 4 starts with three cob walls, walls 4.1-4.3, and three clay (USA) walls, walls 4.4-4.6. The thicknesses have been chosen to represent the walls found here in Devon. The thickness of Devon cob walls ranges from 400 to $750 \mathrm{~mm}$ [21]. The thickness of the cob walls, reported by Keefe in his individual case studies of cob wall failures, have been analysed and show that the average wall thickness is $570 \mathrm{~mm}$, with a standard deviation of $90 \mathrm{~mm}$. A further simplification is applied to the cob walls in this work. Typically real cob walls are protected externally by a lime wash and are finished internally with a lime render. In the following calculations on the thermal properties of cob walls it will be assumed that there are no surface treatments. The thermal properties of Devon cob walls are determined assuming walls of thickness 400,600 , and $800 \mathrm{~mm}$. This will provide a range of properties to reflect those likely to be found in the real buildings and these dimensions will be used throughout the upgrading studies. Clearly, the Devon cob walls 4.1-4.3 and the clay (USA) walls 4.4-4.6 fail the current standard requirements. The steady-state thermal transmittances, $U$-values, range from 0.5 to $0.9 \mathrm{~W} / \mathrm{m}^{2} \mathrm{~K}$ for cob and 1.3-2.1 W/m $\mathrm{m}^{2} \mathrm{~K}$ for clay (USA), and are therefore all well above the $0.35 \mathrm{~W} / \mathrm{m}^{2} \mathrm{~K}$ standard. The Devon cob walls have the lower $U$-values, while the clay (USA) the shorter decrement time lags.

Table 4.

Thermal properties of some proposed sustainable wall constructions

\begin{tabular}{|c|c|c|c|c|}
\hline Wall description & $\begin{array}{l}\text { Thickness } \\
(\mathrm{mm})\end{array}$ & $\begin{array}{l}U \text {-value } \\
\left(W / m^{2} \mathbf{K}\right)\end{array}$ & $\begin{array}{l}\text { Mass } \\
\text { per } \\
\text { unit } \\
\text { area } \\
\left(\mathbf{k g} / \mathbf{m}^{2}\right)\end{array}$ & $\begin{array}{l}\text { Admit } \\
\left(\mathbf{W} / \mathbf{m}^{2}\right.\end{array}$ \\
\hline (4.1) Cob (Devon earth, mean) & 400 & 0.94 & 580 & 3.83 \\
\hline (4.2) Cob (Devon earth, mean) & 600 & 0.66 & 870 & 3.83 \\
\hline
\end{tabular}




\begin{tabular}{|c|c|c|c|c|}
\hline Wall description & $\begin{array}{l}\text { Thickness } \\
(\mathbf{m m})\end{array}$ & $\begin{array}{l}U \text {-value } \\
\left(W / \mathbf{m}^{2} K\right)\end{array}$ & $\begin{array}{l}\text { Mass } \\
\text { per } \\
\text { unit } \\
\text { area } \\
\left(\mathbf{k g} / \mathbf{m}^{2}\right)\end{array}$ & $\begin{array}{l}\text { Admitt } \\
\left(\mathbf{W} / \mathbf{m}^{2}\right.\end{array}$ \\
\hline (4.3) Cob (Devon earth, mean) & 800 & 0.51 & 1160 & 3.83 \\
\hline (4.4) Clay (USA) & 400 & 2.05 & 584 & 5.15 \\
\hline (4.5) Clay (USA) & 600 & 1.56 & 876 & 5.13 \\
\hline (4.6) Clay (USA) & 800 & 1.26 & 1168 & 5.13 \\
\hline \multicolumn{5}{|l|}{ Upgrade cod by adding external glazing } \\
\hline (4.7) $6 \mathrm{~mm}$ external glass, $50 \mathrm{~mm}$ ventilated air cavity, $400 \mathrm{~mm}$ Devon earth & 456 & 0.80 & 595 & 3.83 \\
\hline (4.8) $6 \mathrm{~mm}$ external glass, $50 \mathrm{~mm}$ ventilated air cavity, $600 \mathrm{~mm}$ Devon earth & 656 & 0.59 & 885 & 3.83 \\
\hline (4.9) $6 \mathrm{~mm}$ external glass, $50 \mathrm{~mm}$ ventilated air cavity, $800 \mathrm{~mm}$ Devon earth & 856 & 0.47 & 1175 & 3.83 \\
\hline (4.10) $12 \mathrm{~mm}$ external glass, $50 \mathrm{~mm}$ ventilated air cavity, $400 \mathrm{~mm}$ Devon earth & 462 & 0.79 & 610 & 3.83 \\
\hline (4.11) $12 \mathrm{~mm}$ external glass, $50 \mathrm{~mm}$ ventilated air cavity, $600 \mathrm{~mm}$ Devon earth & 662 & 0.59 & 900 & 3.83 \\
\hline (4.12) $12 \mathrm{~mm}$ external glass, $50 \mathrm{~mm}$ ventilated air cavity, $800 \mathrm{~mm}$ Devon earth & 862 & 0.47 & 1190 & 3.83 \\
\hline
\end{tabular}

To upgrade these cob walls it is proposed to erect an external glass screen, or envelope, around the cob walls to improve the wall to an acceptable thermal standard. Walls 4.7-4.9 have an external leaf of glass $6 \mathrm{~mm}$ thick providing a ventilated air cavity before the cob material. The $U$-values range from 0.47 to $0.8 \mathrm{~W} / \mathrm{m}^{2} \mathrm{~K}$, and are unacceptably high. Walls $4.10-4.12$ have a $12 \mathrm{~mm}$ external glass leaf with ventilated air cavity, and these are also unacceptable with $U$-values of $0.47-0.79 \mathrm{~W} / \mathrm{m}^{2} \mathrm{~K}$. Even when a double glazed external glass screen and ventilated air cavity is added to $600 \mathrm{~mm}$ of cob the $U$-value only falls to $0.49 \mathrm{~W} / \mathrm{m}^{2} \mathrm{~K}$. This proposal of adding a glass screen will not provide sufficient thermal improvement to meet current Building Regulations.

It may be questioned why Table 4 was included, since it only shows wall constructions that are thermally unacceptable in terms of the current Building Regulations. Walls 4.1-4.6 forcefully demonstrate the thermal problem arising with traditional cob walls. Walls 4.7-4.12 show that simply enclosing the cob building in a glass screen, although this is an inexpensive and simple measure, the improvement in $U$-value falls short, this solution does not provide the thermal insulation required.

\subsection{Thermal properties of upgraded earth walls with internal insulated timber frame}


$\underline{\text { Table } 5}$ has a layout similar to Table 4, and gives details of the possible upgrading of existing cob walls by the addition of an internal timber frame with various types and thicknesses of insulation. To gain an overview of the upgrading of earth walls the three earth thicknesses 400, 600 and $800 \mathrm{~mm}$ have again been used together with two differing insulation thicknesses, 100 and $150 \mathrm{~mm}$, each in turn using the two insulating materials paper or wool. There are therefore 12 combinations, and the thermal properties of these 12 upgraded cob walls are given in Table 5. Walls 5.1-5.3 show the three thicknesses of cob, 400, 600 and $800 \mathrm{~mm}$, with $100 \mathrm{~mm}$ of paper insulation. All three walls meet the current Building Regulations with $U$-values 0.26$0.21 \mathrm{~W} / \mathrm{m}^{2} \mathrm{~K}$. Walls 5.4-5.6 are as 5.1-5.3 except that the insulation has been changed to wool. Here the $U$-values are about 4\% smaller, and represent no significant advantage over paper. Walls 5.7-5.9 are again like walls 5.1-5.3, but now the paper insulation layer is $150 \mathrm{~mm}$. The increase in insulation thickness has resulted in a reduction of the $U$-value by about $15 \%$. Again the wool insulation used in walls 5.10-5.12 shows an improved $U$-value. All these walls have low decrement factors, indicating that even with sol-air driven thermal input to the external wall surface, then negligible temperature differences would appear at the internal wall surface. The time lags are in the region of 18-36 h suggesting that any very small daily temperature fluctuations will disappear.

Table 5.

Thermal properties of some proposed upgraded cob wall constructions to satisfy the Building Regulations

Thermally upgraded cob wall with added internal timber frame and insulation

(5.1) $400 \mathrm{~mm}$ cob wall, $50 \mathrm{~mm}$ ventilated air cavity, $19 \mathrm{~mm}$ plywood sheathing, $100 \mathrm{~mm}$ paper insulation (100 mm studding),

(5.2) $600 \mathrm{~mm}$ cob wall, $50 \mathrm{~mm}$ ventilated air cavity, $19 \mathrm{~mm}$ plywood sheathing, $100 \mathrm{~mm}$ paper insulation (100 mm studding),

(5.3) 800 mm cob wall, $50 \mathrm{~mm}$ ventilated air cavity, $19 \mathrm{~mm}$ plywood sheathing, $100 \mathrm{~mm}$ paper insulation (100 mm studding), (5.4) $400 \mathrm{~mm}$ cob wall, $50 \mathrm{~mm}$ ventilated air cavity, $19 \mathrm{~mm}$ plywood sheathing, $100 \mathrm{~mm}$ wool insulation (100 mm studding),

(5.5) $600 \mathrm{~mm}$ cob wall, $50 \mathrm{~mm}$ ventilated air cavity, $19 \mathrm{~mm}$ plywood sheathing, $100 \mathrm{~mm}$ wool insulation (100 mm studding),

(5.6) $800 \mathrm{~mm}$ cob wall, $50 \mathrm{~mm}$ ventilated air cavity, 19 mm plywood sheathing, $100 \mathrm{~mm}$ wool insulation (100 mm studding),

(5.7) $400 \mathrm{~mm}$ cob wall, $50 \mathrm{~mm}$ ventilated air cavity, $19 \mathrm{~mm}$ plywood sheathing, $150 \mathrm{~mm}$ paper insulation (150 mm studding),

(5.8) $600 \mathrm{~mm}$ cob wall, $50 \mathrm{~mm}$ ventilated air cavity, $19 \mathrm{~mm}$ plywood sheathing, $150 \mathrm{~mm}$ paper insulation (150 mm studding),

(5.9) 800 mm cob wall, $50 \mathrm{~mm}$ ventilated air cavity, $19 \mathrm{~mm}$ plywood sheathing, $150 \mathrm{~mm}$ paper insulation (150 mm studding),

(5.10) $400 \mathrm{~mm}$ cob wall, $50 \mathrm{~mm}$ ventilated air cavity, $19 \mathrm{~mm}$ plywood sheathing, $150 \mathrm{~mm}$ wool insulation (150 mm studding)

(5.11) $600 \mathrm{~mm}$ cob wall, $50 \mathrm{~mm}$ ventilated air cavity, $19 \mathrm{~mm}$ plywood sheathing, $150 \mathrm{~mm}$ wool insulation (150 mm studding)

(5.12) $800 \mathrm{~mm}$ cob wall, $50 \mathrm{~mm}$ ventilated air cavity, $19 \mathrm{~mm}$ plywood sheathing, $150 \mathrm{~mm}$ wool insulation (150 mm studding) 


\section{Conclusions}

At the start of this work three aims where identified. To meet aim 1 of this work, the thermal properties of some straw based building materials have been measured using the thermal probe technique to give both the thermal conductivity and the diffusivity. Using some earlier data, theoretical predictions of Devon cob walls with thickness $600 \mathrm{~mm}$ shows that the $U$-value is about twice the acceptable value. Erecting an external glass screen of single or double glazing does not provide sufficient thermal insulation to reduce the cob wall air-to-air thermal transmittance to an acceptable value. Two further conclusions can be drawn from this work to satisfy aims 2 and 3 . Firstly, it is possible to design new earth walls that can satisfy current United Kingdom Building Regulations, Part L. Both traditional cob structures and adobe constructions can be designed to meet the thermal requirements. Secondly, the upgrading of existing cob walls to meet the UK Building Regulations is possible by adding an insulated timber frame to the internal wall surface.

Future work will measure the air-to-air thermal transmittance of Devon cob walls following the recipe reported by the Building Research Establishment [22]. At the same time the thermal properties of the materials in the walls will be determined using the probe technique. Then it will be possible to compare designed thermal transmittances with real built values, the values determined for walls in real buildings with real internal and external environmental conditions.

Finally, the time-dependent thermal properties of the sustainable walls proposed here will be used to model the time-dependent behaviour of some proposed dwellings, with standard dwelling designs and occupancy schedules provided by Allen and Pinney [23]. The Hevacomp software "Gain" uses the admittance method to give hourly building heating and cooling loads along with indoor temperatures, and will therefore allow a preliminary view of the time-dependent behaviour of the modelled buildings. More sophisticated time-dependent studies will be carried out using the Environmental Design Solutions “Thermal Analysis Software”.

\section{References}

[1] The Building Regulations 2000, Conservation of Fuel and Power, Approved document L1 Conservation of fuel and power in dwellings, Effective from 1 April 2002, 2002 Edition, DTLR, The Stationery Office, London.

http://www.sciencedirect.com/science?_ob=RedirectURL\&_method=externObjLink \&_locator=url\&_cdi=5712\&_plusSign=\%2B\&_targetURL=http $\% 253 \mathrm{~A} \% 252 \mathrm{~F} \% 252$ Fwww.safety.odem.gov.uk\%252Fbregs\%252Fbrpub\%252Fad\%252Fad11\%252Findex01.htm (accessed 14 November 2002).

[2] PRe Consultants bv http://www.sciencedirect.com/science?_ob=RedirectURL\&_method=externObjLink 
\&_locator $=$ url\&_cdi $=5712 \&$ _plusSign=\%2B\&_targetURL=http $\% 253 \mathrm{~A} \% 252 \mathrm{~F} \% 252$ Fwww.pre.nl\%252F and

http://www.sciencedirect.com/science?_ob=RedirectURL\&_method=externObjLink \&_locator=url\&_cdi=5712\&_plusSign=\%2B\&_targetURL $=$ http $\% 253 \mathrm{~A} \% 252 \mathrm{~F} \% 252$ Fwww.pre.nl\%252Feco-indicator99\%252Fei99-reports.htm (accessed 25 February 2004).

[3] Greenhouse, “Thermal Mass” simple design guide to sustainable design for dwellings.

http://www.sciencedirect.com/science?_ob=RedirectURL\&_method=externObjLink \&_locator $=$ url\&_cdi $=5712 \&$ _plusSign=\%2B\&_targetURL=http $\% 253 \mathrm{~A} \% 252 \mathrm{~F} \% 252$ Fwww.greenhouse.gov.au\%252Fyourhome\%252Ftechnical\%252Ffs17.htm (accessed 17 February 2004).

[4] English Heritage, State of the Historic Environment 2002 Report, Chapter 2, The Economic Dimension (PDF), English Heritage, London, p. 40.

http://www.sciencedirect.com/science?_ob=RedirectURL\&_method=externObjLink

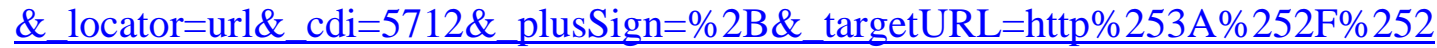
Fwww.heritagecounts.org.uk\%252F/ (accessed 20 February 2004).

[5] National Physical Laboratory, Standards for heat transfer through structures (thermal transmittance).

http://www.sciencedirect.com/science?_ob=RedirectURL\&_method=externObjLink \&_locator $=$ url\&_cdi $=5712$ \&_plusSign=\%2B\&_targetURL $=$ http $\% 253 \mathrm{~A} \% 252 \mathrm{~F} \% 252$ Fwww.npl.co.uk\%252Fthermal\%252Fprojects\%252Fproject4-2.html (accessed 20 February 2004).

[6] Environmental Design CIBSE Guide A, CIBSE, The Yale Press Ltd., London, 1999.

[7] S. Goodhew and R. Griffiths, Analysis of thermal-probe measurements using an iterative method to give sample conductivity and diffusivity data, Applied Energy 77 (2004), pp. 205-223.

[8] Hukseflux Thermal Sensors, Delft, The Netherlands. www.hukseflux.com.

[9] Construction Resources, Claytec unfired claybrick 700, 2DF.

http://www.sciencedirect.com/science?_ob=RedirectURL\&_method=externObjLink \&_locator $=$ url\&_cdi $=5712 \& \_p l u s S i g n=\% 2 B \& \_t a r g e t U R L=h t t p \% 253 A \% 252 F \% 252$ Fwww.hukseflux.com\%252F (accessed 17 February 2004).

[10] L. Dewar, Details of Claytec unfired clay brick 700, 2DF.

http://www.sciencedirect.com/science?_ob=RedirectURL\&_method=externObjLink

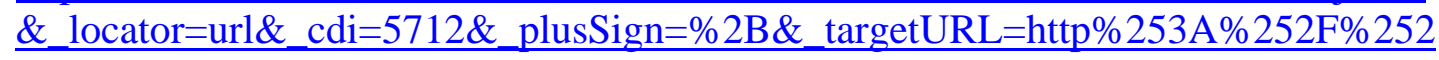
Fwww.hukseflux.com\%252F. Private communication, 1 April 2003.

[11] C. Morgan, Light earth constructions, in: Research Focus, issue 50, Department of Trade and Industry, London, 2002, p. 4. Also see

http://www.sciencedirect.com/science?_ob=RedirectURL\&_method=externObjLink 
\&_locator $=$ url\&_cdi $=5712 \&$ _plusSign=\%2B\&_targetURL=http $\% 253 \mathrm{~A} \% 252 \mathrm{~F} \% 252$ Fwww.hukseflux.com\%252F (accessed 17 February 2004).

[12] Hevacomp Ltd.

http://www.sciencedirect.com/science?_ob=RedirectURL\&_method=externObjLink

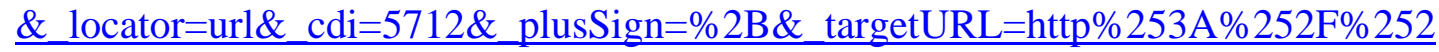
Fwww.hukseflux.com\%252F (accessed 1 March 2004).

[13] S.V. Szokolay, Introduction to architectural science: the basis of sustainable design, Data Sheet 1.1 Thermal Properties of Materials, Architectural Press/Elsevier, Oxford, UK (2004).

[14] Adobe, Mud Brick (Adobe) construction, For details see:

http://www.sciencedirect.com/science?_ob=RedirectURL\&_method=externObjLink \& locator=url\&_cdi $=5712 \&$ \& plusSign=\%2B\& targetURL=http $\% 253 \mathrm{~A} \% 252 \mathrm{~F} \% 252$ Fwww.hukseflux.com\%252F (accessed 17 February 2004).

[15] Warmcel, Recycled newsprint for building insulation, For details see:

http://www.sciencedirect.com/science?_ob=RedirectURL\&_method=externObjLink

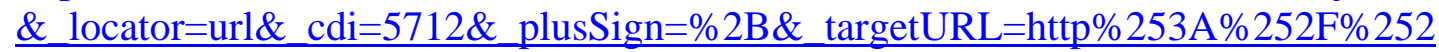
Fwww.hukseflux.com\%252F (accessed 1 March 2004).

[16] Thermafleece, Wool for insulating walls, floors and roofs, For details see: http://www.sciencedirect.com/science?_ob=RedirectURL\&_method=externObjLink \&_locator=url\&_cdi=5712\&_plusSign=\%2B\&_targetURL=http $\% 253 \mathrm{~A} \% 252 \mathrm{~F} \% 252$ Fwww.hukseflux.com\%252F (accessed 1 March 2004).

[17] S. Goodhew, R. Griffiths, D. Short and L. Watson, Some preliminary studies of the thermal properties of Devon cob walls, Proceedings of the Eighth International Conference on the Study and Conservation of Earthen Architecture (Terra 2000) English Heritage, James and James, London (2000), pp. 139-143.

[18] F.P. Incropera and D.P. DeWitt, Introduction to Heat Transfer (3rd ed.), Wiley, New York (1996).

[19] M. Ford, R. Griffiths, L. Watson, The Sandford inventory of earth buildings: a conservator's tool, Journal of Architectural of Conservation, in press.

[20] B.K.Otto, About: sustainability, Design Council, UK. http://www.sciencedirect.com/science?_ob=RedirectURL\&_method=externObjLink

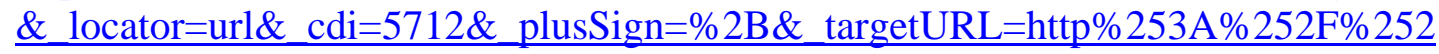
Fwww.hukseflux.com\%252F (accessed 10 March 2004).

[21] L. Keefe, An investigation into the causes of structural failure in traditional cob buildings, MPhil Thesis, University of Plymouth, 1998, unpublished.

[22] Building Research Establishment (BRE) Client Report Number 78132, Field investigations of the thermal performance of construction elements as built, BRE Ltd., Watford, UK, 2000. 
[23] E.A. Allen and A.A. Pinney, Standard dwellings for modelling: details of dimensions, construction and occupancy schedules, Building Environmental Performance Analysis Club (BEPAC) Technical note 90/2, Building Research Establishment, Watford, UK (1990).

Corresponding author. Tel.: +44 1752 233605; fax: +44 1752233634. 